
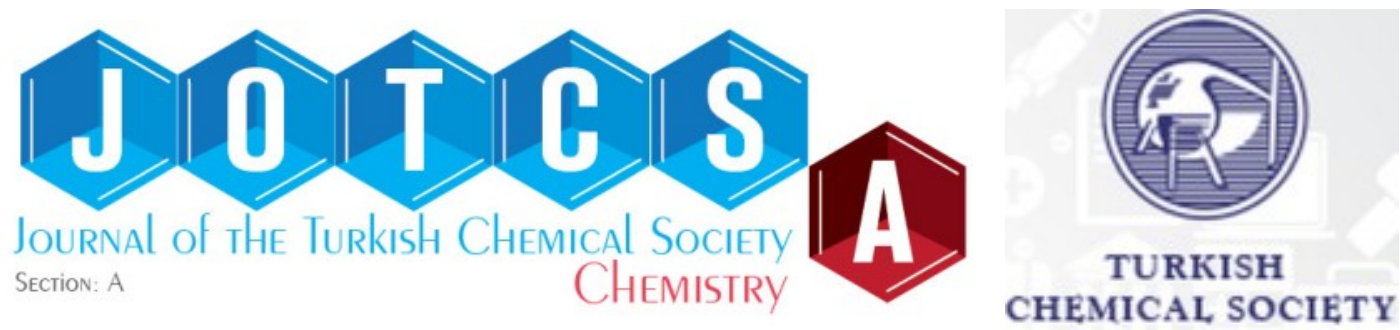

\title{
Eco-friendly Synthesis of Quinoxaline Derivatives Using Mineral Fertilizers as Heterogeneous Catalysts
}

\author{
Badr Malek $\triangle D$, Imane Bahammou $\triangle D$, Omar Zimou $\triangle D$, Achraf El Hallaoui $\triangle(D$, Rachida \\ Ghailane $\triangle D$, Said Boukhris $\triangle D$, Abdelaziz Souizi* $\triangle D$
}

Laboratory of Organic, Organometallic and Theoretical Chemistry, University Ibn Tofail, B.P. 133, Kenitra, Morocco

Abstract: The synthesis of quinoxaline derivatives were heterogeneously catalyzed by phosphate-based catalyst fertilizers, MAP, DAP, or TSP. The reaction affords the desired products in excellent yields at ambient temperature. A series of studies were conducted to investigate the effect of solvent reaction, its volume, and catalyst amount. A study of the recyclability of catalysts removed from the reaction mixture by simple filtration was also carried out to find that the three phosphate-based catalysts retain their catalytic activities up to six cycles.

Keywords: Phosphate, Fertilizers, MAP, DAP, TSP, Quinoxaline, Heterogeneous catalysts.

Submitted: June 12, 2019. Accepted: April 24, 2020.

Cite this: Malek B, Bahammou I, Zimou O, El Hallaoui A, Ghailane R, Boukhris S, et al. Eco-friendly Synthesis of Quinoxaline Derivatives Using Mineral Fertilizers as Heterogeneous Catalysts. JOTCSA. $2020 ; 7(2): 427-40$.

DOI: https://doi.org/10.18596/jotcsa.577101.

*Corresponding author. E-mail: Souizi@yahoo.com (A. Souizi), Tel: +212661183260.

\section{INTRODUCTION}

Since the US Environmental Protection Agency (EPA) had developed the concept of "green chemistry" to protect human health and environment (1), enormous research efforts have been devoted to designing clean and eco-friendly chemical processes (2-4). In this area, considerable interests have focused on heterogeneous catalysis (5-7) due to its advantages to reduce energy consumption but to recover and recycle the used catalyst. Thereby, a large variety of heterogeneous catalysts have been developed and widely used to carry out numerous organic syntheses (8). Among the greener catalysts developed, phosphate-based minerals appear as the obvious choice for Moroccan researchers as they represent the first mining wealth of their country. For this reason, they contribute to the valorization of these minerals as promising catalysts. S. Sebti and co-workers were the first team to introduce natural (9), doped (10) or modified (11) phosphate not only as heterogeneous catalysts for organic reactions but also as the support of metal catalysts (12-13).

Motivated by the desire to introduce a new generation of phosphate-based heterogeneous catalysts, our laboratory was particularly interested in the catalytic performance evaluation of some phosphate fertilizers for Knoevenagel condensation and 1-(benzothiazolylamino)-methyl-1-2-naphthol derivatives (14-15).

In continuation of our ongoing effort to extend the application of these novel fertilizer phosphates as green and reusable heterogeneous catalysts, we develop in the present paper a straightforward and efficient process to synthesize quinoxaline derivatives utilizing phosphate-based catalysts, mono-ammonium phosphate (MAP), di-ammonium phosphate (DAP), or triple superphosphate (TSP).

The quinoxaline derivatives are a class of nitrogencontaining fused heterocyclic compounds, which 
attracted considerable interest since their basic skeleton involved as a core structure of several drug molecules such as quinacillin (15), brimonidine (16), varenicline (17), clofazimine (18), echinomycin (1920) and actinomycin (21). Some other quinoxalinecontaining compounds have shown many biological properties (22), such as antimicrobial (23), antidiabetic (24), anti-inflammatory (25), antioxidant (25), anticancer (26), antileishmanial and antitrypanosomal (27) activities. Additionally, quinoxaline derivatives act as inhibitors of the aldose reductase enzyme (28) and the kinase protein (29). Furthermore, the quinoxaline structural nucleus has recently identified to possess inhibitory effects on the corrosion of some metals (30-32).

In light of their importance, numerous methods have been designed to synthesize quinoxaline derivatives. Most broadly, they involve 1,4-addition of 1,2-diamines to diazenylbutenes (33), oxidative cyclization of a-haloketones and 1,2-diamines (34), oxidative coupling of epoxides with ene-1,2diamines (35), and condensation of 1,2-diamines with 1,2-dicarbonyl compounds (36-37). The latter method was chosen as the reaction model.

\section{EXPERIMENTAL}

\section{Chemicals and instruments}

Chemicals were purchased from Fluka or Aldrich companies. The spectral data were compared with those of the known compounds reported in the literature. Melting points were recorded on a Wagner \& Munz HEIZBANK Kofler bench. Thin layer chromatography (TLC) on silica gel SIL G/UV 254 plates were used to monitor the progress of the reactions.

\section{Synthesis of quinoxaline derivatives: General procedure}

In a typical reaction, to a solution of 1,2 -diamine (1 $\mathrm{mmol}$ ) and 1,2-dicarbonyl (1 mmol) in EtOH (2 mL) was added phosphate-based catalyst MAP, DAP or TSP $(0.006 \mathrm{~g})$. The resulting mixture stirred at 800 $\mathrm{rpm}$ at ambient temperature for appropriate reaction time as indicated by TLC. The solid product formed was dissolved in hot $\mathrm{EtOH}$ and filtered to separate the catalyst, and the resulting filtrate was placed in ice-bath to give a pure product as crystals. All prepared products were identified as based on comparison of their melting points and their ${ }^{1} \mathrm{H}$ NMR and ${ }^{13} \mathrm{C}$ NMR data with authentic samples reported in the literature. Supplementary material includes the NMR data is joined to this paper.

\section{Recyclability of MAP, DAP and TSP}

The recyclability of the catalyst was examined using the model reaction under optimized reaction conditions. The catalyst is recovered by simple filtration at the end of the reaction, washed with hot $\mathrm{EtOH}$, dried at oven at $80{ }^{\circ} \mathrm{C}$ for 6 hours, and then reused.

\section{RESULTS AND DISCUSSION}

In a preliminary study, the condensation of 1,2diamines 1 with 1,2-dicarbonyl 2 (Scheme 1) chosen as a test reaction for the catalytic activity of catalysts MAP, DAP, and TSP. Table 1 gathers the results and noticeably displays that in the presence of catalysts, the reaction led to the expected product in higher yields (94-99\%) within shorter reaction times (Table 1 , entries $2-4$ ).<smiles>Nc1ccccc1N</smiles>

1<smiles>O=C(C(=O)c1ccccc1)c1ccccc1</smiles>

2<smiles>c1ccc(-c2nc3ccccc3nc2-c2ccccc2)cc1</smiles>

$3 a$

Scheme 1. Condensation of 1,2-diamines with 1,2-dicarbonyl compounds.

Table 1. Results and physical characteristics of 2,3-diphenylquinoxaline $\mathbf{3 a .}$

\begin{tabular}{llll}
\hline Entry & Catalyst & Time $^{\mathbf{a}}$ & Yield $^{\mathbf{b}} \mathbf{( \% )}$ \\
\hline 1 & - & 60 & 23 \\
2 & MAP & 4 & 94 \\
3 & DAP & 2 & 99 \\
4 & TSP & 2 & 96 \\
\hline
\end{tabular}

a Time reported in min monitored by TLC. ${ }^{\mathrm{b}}$ Isolated yields.

These encouraging results prompted us to investigate the solvent effect on the reaction. The results displayed in Table 2 show that the reagents react efficiently in the different solvents. However, the yields decreased smoothly when the reaction is carrying out in cyclohexane and THF. The best yields are obtained in EtOH. Consequently, we chose it as an optimal solvent for this reaction to avoid the use of the toxic solvent and thus to contribute to the protection of the environment. 
Table 2. Solvent effect on the quinoxaline $\mathbf{3 a}$ synthesis ${ }^{\text {a }}$.

\begin{tabular}{|c|c|c|c|c|}
\hline Entry & Solvent & Catalyst & Time (min) & Yield $^{\mathbf{b}}(\%)$ \\
\hline 1 & \multirow{3}{*}{$\mathrm{EtOH}$} & MAP & 4 & 94 \\
\hline 2 & & DAP & 2 & 99 \\
\hline 3 & & TSP & 2 & 96 \\
\hline 4 & \multirow{3}{*}{$\mathrm{MeOH}$} & MAP & 4 & 95 \\
\hline 5 & & DAP & 2 & 96 \\
\hline 6 & & TSP & 2 & 90 \\
\hline 7 & \multirow{3}{*}{ Isopropanol } & MAP & 4 & 98 \\
\hline 8 & & DAP & 2 & 96 \\
\hline 9 & & TSP & 2 & 89 \\
\hline 10 & \multirow{3}{*}{$\mathrm{CH}_{3} \mathrm{CN}$} & MAP & 4 & 92 \\
\hline 11 & & DAP & 2 & 95 \\
\hline 12 & & TSP & 2 & 94 \\
\hline 13 & \multirow{3}{*}{ AcOEt } & MAP & 4 & 92 \\
\hline 14 & & DAP & 2 & 94 \\
\hline 15 & & TSP & 2 & 94 \\
\hline 16 & \multirow{3}{*}{ Dioxane } & MAP & 4 & 94 \\
\hline 17 & & DAP & 2 & 93 \\
\hline 18 & & TSP & 2 & 92 \\
\hline 19 & \multirow{3}{*}{$\mathrm{CHCl}_{3}$} & MAP & 4 & 92 \\
\hline 20 & & DAP & 2 & 93 \\
\hline 21 & & TSP & 2 & 90 \\
\hline 22 & \multirow{3}{*}{ Cyclohexane } & MAP & 4 & 87 \\
\hline 23 & & DAP & 2 & 86 \\
\hline 24 & & TSP & 2 & 82 \\
\hline 25 & \multirow{3}{*}{ THF } & MAP & 4 & 73 \\
\hline 26 & & DAP & 2 & 78 \\
\hline 27 & & TSP & 2 & 74 \\
\hline
\end{tabular}
catalyst, r.t; ${ }^{\text {b }}$ Isolated yields.

Further experiments were conducted to determine the optimum catalyst loading. As revealed in Figure 1 , yields increase smoothly with about $1 \%$ when DAP amount increases, and decrease smoothly with $2 \%$ or $1 \%$ when MAP and TSP amounts increase, this result allows us to deduce that the amount of the optimal catalyst is $0.003 \mathrm{~g}$, thus this quantity is widely sufficient to give good yields at $96 \%$ for MAP, at $98 \%$ for DAP and at $97 \%$ for TSP. One can also notice that the reaction times are concise 4, 2 and 2 min in the presence of MAP, DAP, and TSP catalysts, respectively.

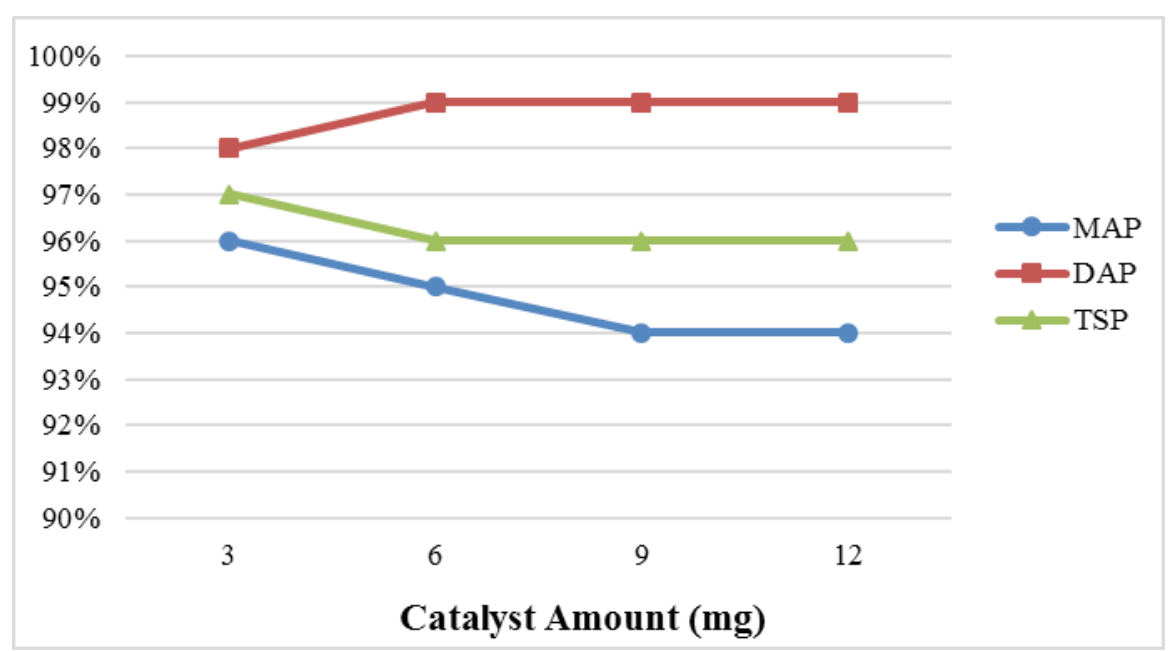

Figure 1. Effect of the catalyst amount on the quinoxaline $\mathbf{3 a}$ synthesis.

In order to explore the reliability of the protocol developed to synthesize the quinoxaline derivatives, various aryl 1,2-diamines were condensed with various 1,2-dicarbonyl compounds (Scheme 2) under the optimal reaction conditions. Table 3 shows that the heterogeneous catalysts MAP, DAP, 
and TSP afford the products in high to excellent yields $89-99 \%$ in short reaction times $2-4 \mathrm{~min}$.

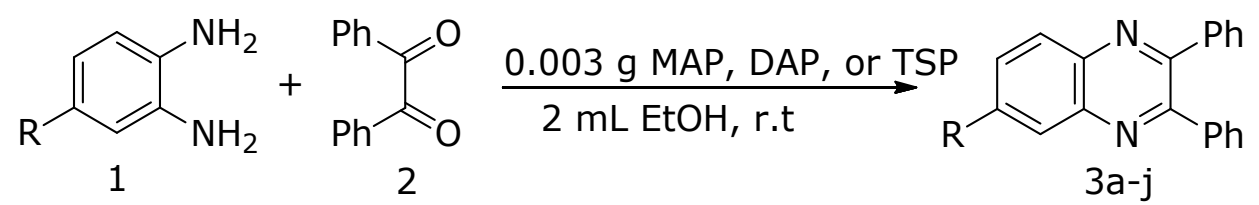

Scheme 2. Condensation of aryl 1,2-diamines with 1,2-dicarbonyl compound.

Table 4 collects the yields and reaction times of the condensation of 1,2-diamines with 1,2-dicarbonyl catalyzed by MAP, DAP, and TSP and those brought out in the literature. As can be seen, phosphate fertilizers MAP, DAP, and TSP underwent the reaction more rapidly than $\mathrm{Fe}_{3} \mathrm{O}_{4} @ \mathrm{SiO}_{2}$-imid-PMA ${ }^{n}$, $\mathrm{VOSO}_{4}$, and $\mathrm{MIL}-101-\mathrm{Cr}-\mathrm{NH}-\mathrm{RSO}_{3} \mathrm{H}$, though the yields were comparable.

Table 4. Comparison between the present results and those given in the literature.

\begin{tabular}{|c|c|c|c|c|c|}
\hline Entry & Catalyst & Condition & $\begin{array}{l}\text { Time } \\
\text { (min) }\end{array}$ & $\begin{array}{l}\text { Yield } \\
(\%)\end{array}$ & Ref \\
\hline 1 & $\mathrm{Fe}_{3} \mathrm{O}_{4} @ \mathrm{SiO}_{2}-\mathrm{imid}-\mathrm{PMA}^{\mathrm{n}}(0,5 \mathrm{~mol} \%)$ & EtOH, r.t. & 10 & 97 & (38) \\
\hline 2 & $\mathrm{VOSO}_{4}(3 \mathrm{~mol} \%)$ & EtOH, r.t. & 20 & 96 & (39) \\
\hline 3 & $\begin{array}{l}\mathrm{MIL}-101-\mathrm{Cr}-\mathrm{NH}-\mathrm{RSO}_{3} \mathrm{H} \quad(3.9 \text { mol\%- } \\
\left.\mathrm{SO}_{3} \mathrm{H}\right)\end{array}$ & $\mathrm{MeOH}, 45^{\circ} \mathrm{C}$ & 12 & 93 & $(40)$ \\
\hline 4 & MAP $(0.003 \mathrm{~g})$ & EtOH, r.t. & 4 & 96 & This work \\
\hline 5 & DAP $(0.003 \mathrm{~g})$ & EtOH, r.t. & 2 & 98 & This work \\
\hline 6 & TSP $(0.003 \mathrm{~g})$ & EtOH, r.t. & 2 & 97 & This work \\
\hline
\end{tabular}

The catalytic efficiency of the catalyst is determined not only by its capacity to lead to the formation of the desired product with a good yield and short reaction time but also by its recyclability and its natural regeneration. Finally, it seemed necessary to check the reusability of the three catalysts (MAP, DAP, and TSP) in the optimum reaction conditions.

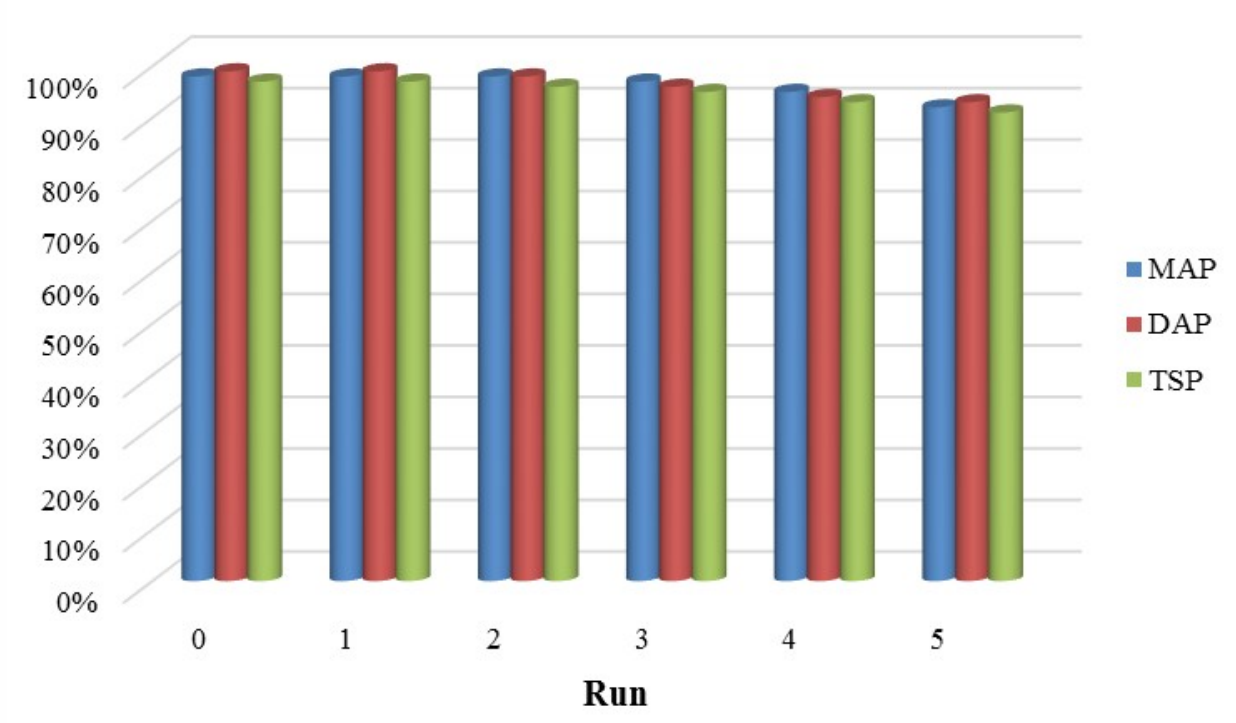

Figure 2. Recyclability of MAP, DAP, and TSP $(0.003 \mathrm{~g})$ in the condensation of 1,2 -diamines with $1,2-$ dicarbonyl compounds at optimal conditions.

The catalysts remain functional throughout the six runs with a slight loss of their catalytic capacity that can be estimated by about $5 \%$ in yield. 
Table 3. Quinoxaline derivatives synthesis catalyzed by MAP, DAP, and TSP at room temperature ${ }^{a}$

a Reaction conditions: 1,2-diamine $(1 \mathrm{mmol})$ and 1,2-dicarbonyl $(1 \mathrm{mmol})$, EtOH ( $2 \mathrm{~mL}), 0.003 \mathrm{~g}$ of catalyst, r.t. ${ }^{\mathrm{b}}$ Isolated yields.

\begin{tabular}{|c|c|c|c|c|c|c|c|c|}
\hline Entry & aryl 1,2-diamines & $\begin{array}{c}\text { 1,2- } \\
\text { dicarbonyl }\end{array}$ & Product & $\begin{array}{c}\text { Molecular } \\
\text { weight } \\
(\mathrm{g} / \mathrm{mol})\end{array}$ & Catalyst & $\begin{array}{l}\text { Time } \\
\text { (min) }\end{array}$ & $\begin{array}{l}\text { Yield }^{\mathrm{b}} \\
(\%)\end{array}$ & TON \\
\hline
\end{tabular}

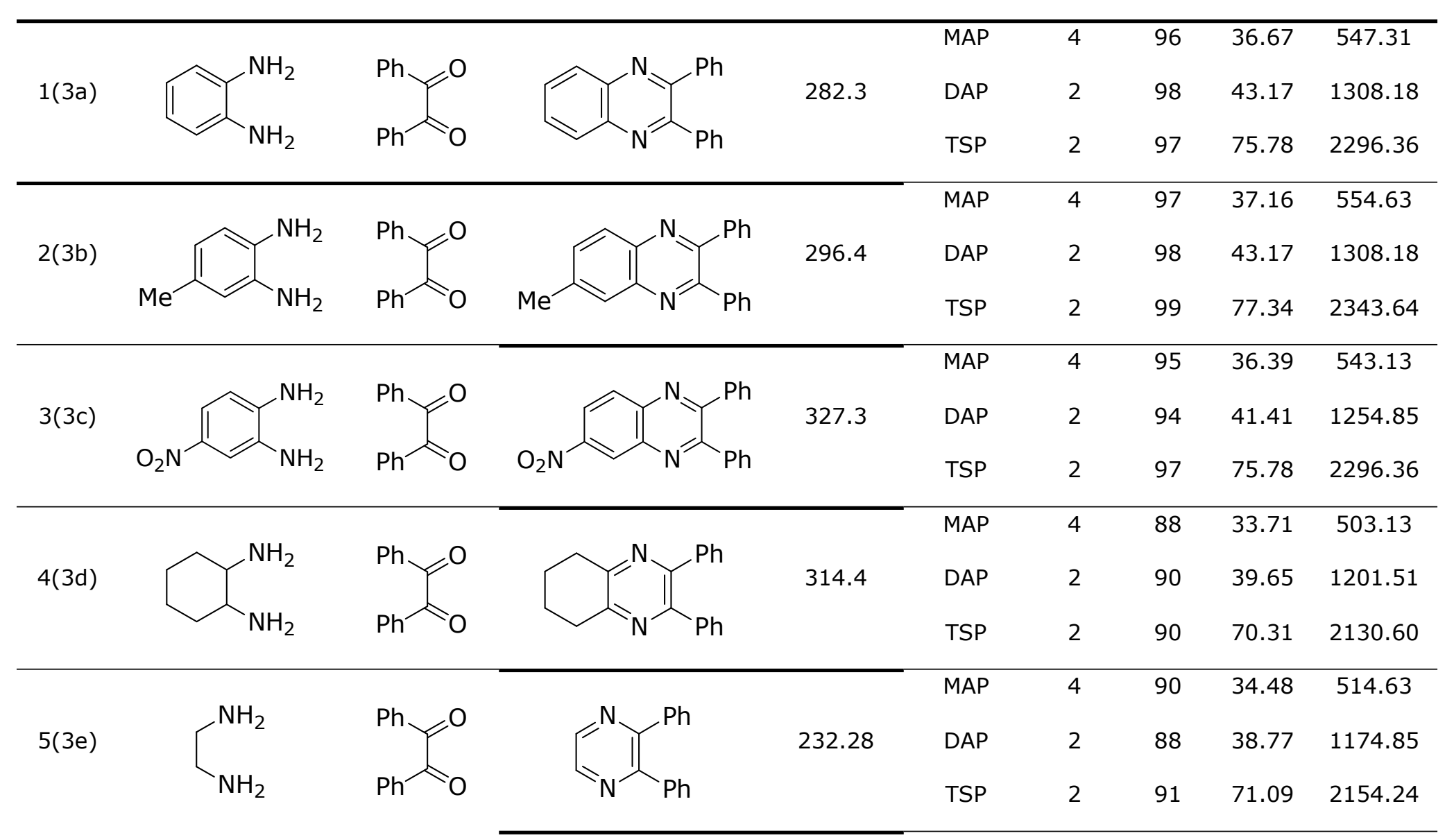




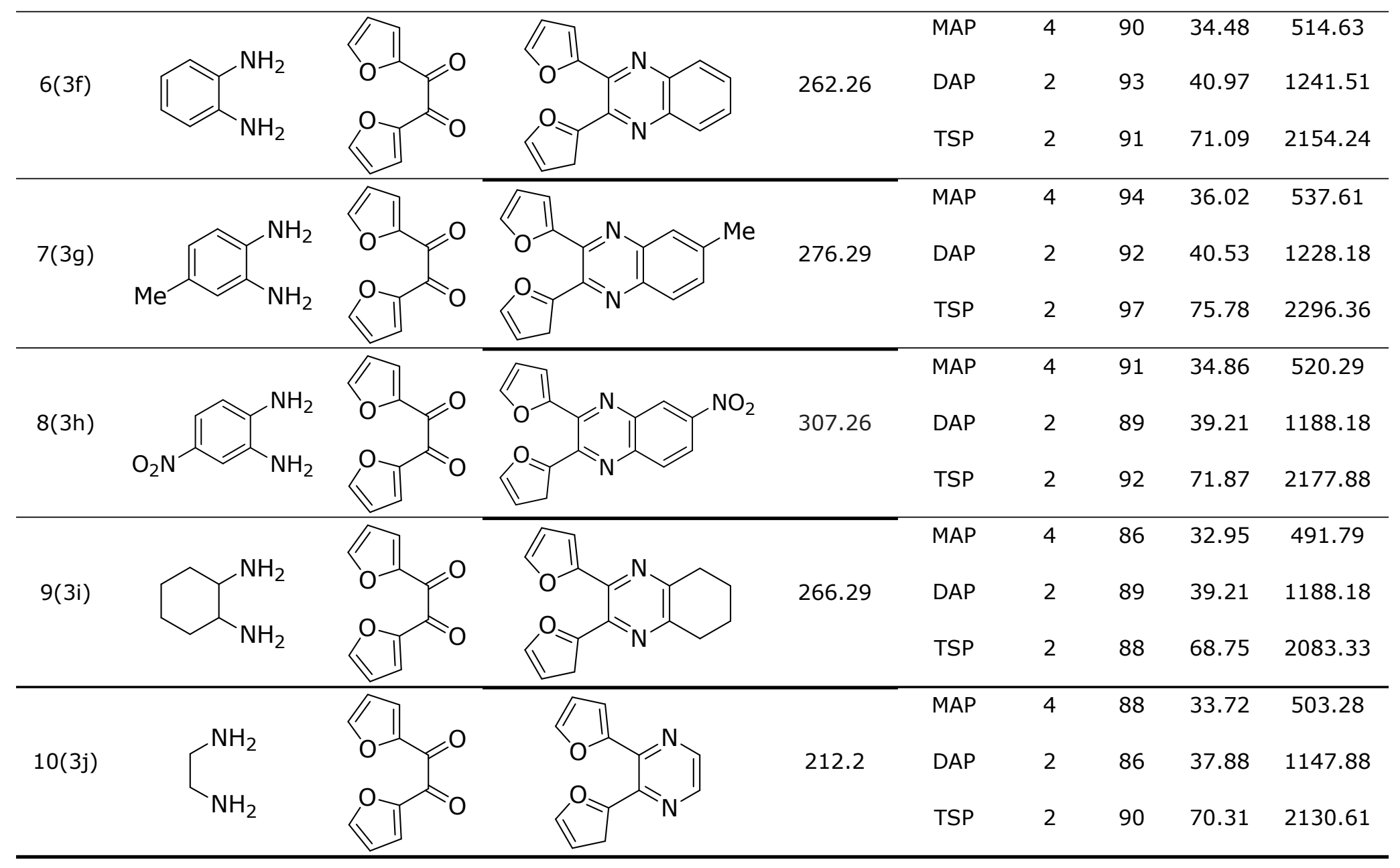




\section{CONCLUSION}

To sum up the present study, phosphate-based fertilizers MAP, DAP, and TSP act as active heterogeneous catalysts for the synthesis of quinoxalines from various 1,2-diamines and 1,2dicarbonyl compounds at ambient temperature. The optimum reaction conditions were not determined only by choice of the "greener" solvent and its volume, but also by the determination of the most appropriate weight of the catalyst, in order to present an environmentally benign protocol for this synthesis. Moreover, the study of the recyclability results shows that the catalysts can be quickly recovered and reused for at least six runs.

\section{REFERENCES}

1. Anastas PT, Warner JC. Green Chemistry: Theory and Practice. Oxford 1998; 29.

2. Xu F, Wang C, Wang $H$, Li X, Wan B. Eco-friendly synthesis of pyridines via rhodium-catalyzed cyclization of diynes with oximes. Green Chemistry 2015; 17(2): 799803.

3. Shingalapur RV, Hosamani KM. An Efficient and EcoFriendly Tungstate Promoted Zirconia (WO x /ZrO2) Solid Acid Catalyst for the Synthesis of 2-Aryl Benzimidazoles. Catalysis Letters 2010; 137(1-2): 63-8.

4. Chakrabarty M, Sarkar S. Novel clay-mediated, tandem addition-elimination-(Michael) addition reactions of indoles with 3-formylindole: an eco-friendly route to symmetrical and unsymmetrical triindolylmethanes. Tetrahedron Letters 2002; 43(7): 1351-3.

5. Shu XZ, Nguyen S C, He Y, Oba F, Zhang Q, Canlas C, Somorjai GA, Alivisatos AP, Toste FD. Silica-Supported Cationic Gold(I) Complexes as Heterogeneous Catalysts for Regio- and Enantioselective Lactonization Reactions. J. Am. Chem. Soc. 2015; 137(22): 7083-6.

6. Sun J, Zhan WW, Akita $T$, Xu Q. Toward Homogenization of Heterogeneous Metal Nanoparticle Catalysts with Enhanced Catalytic Performance: Soluble Porous Organic Cage as a Stabilizer and Homogenizer. J. Am. Chem. Soc. 2015; 137(22): 7063-6.

7. Chughtai AH, Ahmad N, Younus HA, Laypkov A, Verpoort $F$. Metal-organic frameworks: versatile heterogeneous catalysts for efficient catalytic organic transformations. Chemical Society Reviews 2015; 44(19): 6804-49.

8. Pirkanniemi K, Sillanpää M. Heterogeneous water phase catalysis as an environmental application: a review. Chemosphere 2002(10); 48: 1047-60.

9. Abba MO, Gonzalez-DelaCruz VM, Colón G, Sebti S, Caballero A. In situ XAS study of an improved natural phosphate catalyst for hydrogen production by reforming of methane. Applied Catalysis B: Environmental 2014; 150-151: 459-65.

10. Sebti S, Smahi A, Solhy A. Natural phosphate doped with potassium fluoride and modified with sodium nitrate: efficient catalysts for the Knoevenagel condensation. Tetrahedron Letters 2002; 43(10): 1813-5.
11. Ramananarivo HR, Solhy A, Sebti J, Smahi A, Zahouily M, Clark J, Sebti S. An Eco-Friendly Paradigm for the Synthesis of a-Hydroxyphosphonates Using SodiumModified Fluorapatite under Solventless Conditions. ACS Sustainable Chemistry \& Engineering 2013; 1(4): 403-9.

12. Hassine A, Sebti S, Solhy A, Zahouily M, Len C, Hedhili MN, Fihri A. Palladium supported on natural phosphate: Catalyst for Suzuki coupling reactions in water. Applied Catalysis A: General 2013; 450: 13-8.

13. Hassine A, Bouhrara M, Sebti S, Solhy A, Mahfouz R, Luart D, Len C, Fihri A. Natural Phosphate-supported Palladium: A Highly Efficient and Recyclable Catalyst for the Suzuki-Miyaura Coupling Under Microwave Irradiation. Current Organic Chemistry 2014; 18(24): 3141-8.

14. Bahammou I, Esaady A, Boukhris S, Ghailane R, Habbadi N, Hassikou A, Souizi A. Direct use of mineral phosphate fertilizers MAP, DAP, and TSP as heterogeneous catalysts in organic reactions. Mediterr.J.Chem., 2016; 5(6): 615-23.

15. Zimou O, Malek B, Elhallaoui A, Ghailane T, Ghailane $R$, Boukhris $S$, Habbadi N, Hassikou A, Souizi A. Valorization of the Phosphate Fertilizers Catalytic Activity in 1- (Benzothiazolylamino) Methy I-2-Naphthol Derivatives Synthesis. Bulletin of Chemical Reaction Engineering \& Catalysis 2019; 14 (2): 238-46.

16. Hugo WB, Stretton RG. Action of Quinacillin on Staphylococcus aureus. Nature 1964; 202: 1217.

17. Toris CB, Gleason ML, Camras CB, Yablonski ME. Effects of Brimonidine on Aqueous Humor Dynamics in Human Eyes. Archives of Ophthalmology 1995; 113(12): 1514-7.

18. Chávez JJE, Merino V, Cervantes ML, Cruz IMR, Guerrero DQ, Quintanar AG. The Use of Iontophoresis in the Administration of Nicotine and New Non-Nicotine Drugs through the Skin for Smoking Cessation. Current Drug Discovery Technologies 2009; 6(3): 171-85.

19. Arbiser JL, Moschella SL. Clofazimine: A review of its medical uses and mechanisms of action. Journal of the American Academy of Dermatology 1995; 32(2): 241-7.

20. Dell A, Williams DH, Morris HR, Smith GA, Feeney J, Roberts GCK. Structure revision of the antibiotic echinomycin. J. Am. Chem. Soc. 1975; 97(9): 2497-502.

21. Bailly C, Echepare S, Gago F, Waring M. (1999) Recognition elements that determine affinity and sequence-specific binding to DNA of $2 \mathrm{QN}$, a biosynthetic bis-quinoline analogue of echinomycin, Anti-Cancer Drug Design 1999; 14(3): 291-303.

22. Taylor J. Inhibition of interferon action by actinomycin. Biochemical and biophysical research communications 1964; 14: 447-51.

23. Pereira J A, Pessoa A M, Cordeiro MNDS, Fernandes $R$, Prudêncio C, Noronha JP, Vieira M. Quinoxaline, its derivatives and applications: A State of the Art review. European Journal of Medicinal Chemistry 2015; 97: 66472 
24. Vieira $M$, Pinheiro $C$, Fernandes $R$, Noronha JP, Prudêncio C. Antimicrobial activity of quinoxaline 1,4dioxide with 2- and 3-substituted derivatives. Microbiological Research 2014; 169(4): 287-93.

25. Bahekar RH, Jain MR, Gupta AA, Goel A, Jadav PA, Patel DN, Prajapati VM, Patel PR. (2007) Synthesis and Antidiabetic Activity of 3,6,7-Trisubstituted-2-(1H-imidazol2-ylsulfanyl)quinoxalines and Quinoxalin-2-yl isothioureas. Arch. Pharm. Chem. Life Sci, 340(7): 359-66.

26. Burguete A, Pontiki E, Hadjipavlou-Litina D, Ancizu $S$, Villar R, Solano B, Moreno E, Torres EE, Pérez S, Aldana I, Monge A. (2011) Synthesis and Biological Evaluation of New Quinoxaline Derivatives as Antioxidant and AntiInflammatory Agents. Chemical Biology \& Drug Design 2011 ; 77(4): 255-67.

27. Cogo J, Kaplum V, Sangi DP, Ueda-Nakamura T, Corrêa AG, Nakamura CV. Synthesis and biological evaluation of novel 2,3-disubstituted quinoxaline derivatives as antileishmanial and antitrypanosomal agents. European Journal of Medicinal Chemistry 2014; 90: 107-23.

28. Tseng $\mathrm{CH}$, Chen YR, Tzeng CC, Liu W, Chou CK, Chiu CC, Chen YL. Discovery of indeno[1,2-b]quinoxaline derivatives as potential anticancer agents. European Journal of Medicinal Chemistry 2015; 108: 258-73.

29. Sarges R, Lyga J W. Synthesis and aldose reductase inhibitory activity of $\mathrm{N}-1, \mathrm{~N}$-4-disubstituted 3,4-dihydro$2(1 \mathrm{H})$-quinoxalinone derivatives. Journal of Heterocyclic Chemistry 1988; 25(5): 1475-9.

30. Schepetkin IA, Kirpotina LN, Khlebnikov AI, Hanks TS, Kochetkova I, Pascual DW, Jutila MA, Quinn MT. Identification and Characterization of a Novel Class of CJun N-terminal Kinase Inhibitors. Molecular Pharmacology 2012; 81(6): 832-45.

31. Saranya J, Sounthari P, Parameswari K, Chitra S. Acenaphtho[1,2-b]quinoxaline and acenaphtho[1,2b]pyrazine as corrosion inhibitors for mild steel in acid medium, Measurement 2016; 77: 175.

32. Olasunkanmi LO, Kabanda MM, Ebenso EE. Quinoxaline derivatives as corrosion inhibitors for mild steel in hydrochloric acid medium: Electrochemical and quantum chemical studies. Physica E 2016; 76: 109-26.

33. Zarrouk A, Zarrok H, Salghi R, Hammouti B, Al-Deyab
SS, Touzani R, Bouachrine M, Warad I, Hadda T B. A Theoretical Investigation on the Corrosion Inhibition of Copper by Quinoxaline Derivatives in Nitric Acid Solution, International Journal of Electrochemical Science 2012; 7: 6353-64.

34. Aparicio D, Attanasi OA, Filippone $P$, Ignacio $R$, Lillini $S$, Mantellini F, Palacios F, Santos JMDL. Straightforward Access to Pyrazines, Piperazinones, and Quinoxalines by Reactions of 1,2-Diaza-1,3-butadienes with 1,2-Diamines under Solution, Solvent-Free, or Solid-Phase Conditions. Journal of Organic Chemistry 2006; 71(16): 5897-905.

35. Singh SK, Gupta P, Duggineni S, Kundu B. Solid Phase Synthesis of Quinoxalines. Synlett 2003; 14: 2147-50.

36. Taylor EC, Maryanoff CA, Skotnickilc JS. Heterocyclization with cyano and sulfonyl epoxides. Preparation of quinoxalines and tetrahydro quinoxalines. Journal of Organic Chemistry 1980; 45(12): 2512-5.

37. Kamal A, Babu KS, Hussaini SA, Mahesh R, Alarifi A. Amberlite IR-120H, an efficient and recyclable solid phase catalyst for the synthesis of quinoxalines: a greener approach. Tetrahedron Letters 2015; 56(21): 2803-8.

38. Huang T, Jiang D, Chen J, Gao W, Ding J, Wu H. Silica Sulfuric Acid (SSA)/Polyethylene Glycol (PEG) as a Recyclable System for the Synthesis of Quinoxalines and Pyrazines, Synthetic Communications 2011; 41(22): 333443

39. Javidi J, Esmaeilpour M. $\mathrm{Fe}_{3} \mathrm{O}_{4} @ \mathrm{SiO}_{2}$-imid-PMAn magnetic porous nanosphere as recyclable catalyst for the green synthesis of quinoxaline derivatives at room temperature and study of their antifungal activities. Materials Research Bulletin 2016; 73: 409-22.

40. Digwal CS, Yadav U, Sakla AP, Ramya PVS, Aaghaz S, Kamal A. $\mathrm{VOSO}_{4}$ catalyzed the highly efficient synthesis of benzimidazoles, benzothiazoles, and quinoxalines. Tetrahedron Letters 2016; 57(36): 4012-6.

41. Andriamitantsoa RS, Wang J, Dong W, Gao H, Wang G. $\mathrm{SO}_{3} \mathrm{H}$-functionalized metal-organic frameworks: an efficient heterogeneous catalyst for the synthesis of quinoxaline and derivatives. RSC Advances 2016; 6: 35135-43. 


\title{
Eco-friendly Synthesis of Quinoxaline Derivatives Using Mineral Fertilizers as Heterogeneous Catalysts
}

\author{
Badr Malek, Imane Bahammou, Omar Zimou, Achraf El Hallaoui, Rachida Ghailane, Said Boukhris, \\ Abdelaziz Souizi*
}

Laboratory of Organic, Organometallic and Theoretical Chemistry, University Ibn Tofail, B.P. 133, Kenitra, Morocco

* Correspondence: Souizi@yahoo.com (A. Souizi),

Tel: +212661183260

\section{Supplementary Information}

2,3-diphenylquinoxaline (3a, Table 3, Entry 1). M.p.: $127-128^{\circ} \mathrm{C}\left(126-127^{\circ} \mathrm{C}{ }^{36-37}\right) ;{ }^{1} \mathrm{H}$ NMR $(300$ $\mathrm{MHz}$, DMSO-d6): $\delta(\mathrm{ppm}): 7.32-7.36(\mathrm{~m}, 6 \mathrm{H})$; 7.42-7.46 (m, 4H); 7.86-7.88 (m, 2H); 8.14-8.16 $(\mathrm{m}, 2 \mathrm{H}) \cdot{ }^{13} \mathrm{C}$ NMR $(300 \mathrm{MHz}$, DMSO-d6): $\delta(\mathrm{ppm})$ : $128.50 ; 129.22 ; 129.26 ; 130.16 ; 130.84 ; 139.23$; $140.93 ; 153.49$.

6-methyl-2,3-diphenylquinoxaline (3b, Table 3, Entry 2). M.p.: $121-122^{\circ} \mathrm{C}\left(120-122^{\circ} \mathrm{C}^{36-37}\right) ;{ }^{1} \mathrm{H}$ NMR (300 MHz, DMSO-d6): $\delta$ (ppm): 2.47 (s, 3H); 7.30-7.47 (m, 6H); 7.68-7.71 (m, 4H); $7.92(\mathrm{~m}$, $1 \mathrm{H}) ; 8.01(\mathrm{~m}, 1 \mathrm{H}) ; 8.04(\mathrm{~m}, 1 \mathrm{H}) .{ }^{13} \mathrm{C}$ NMR (300 $\mathrm{MHz}, \mathrm{DMSO}-\mathrm{d} 6): \delta(\mathrm{ppm}): 21.83 ; 127.96 ; 128.82$; $129.15 ; 130.13$; 133.02 ; 139.42; 141.00; 152.56; 153.30 .

6-nitro-2,3-diphenylquinoxaline (3c, Table 3, Entry 3). M.p.: $141-142^{\circ} \mathrm{C}\left(140-142{ }^{\circ} \mathrm{C}{ }^{37}\right) ;{ }^{1} \mathrm{H}$ NMR (300 $\mathrm{MHz}$, DMSO-d6): $\delta(\mathrm{ppm}): 7.36-7.46(\mathrm{~m}, 6 \mathrm{H})$; 7.47-7.54 (m, 4H); $8.38(\mathrm{~m}, 1 \mathrm{H}) ; 8.58(\mathrm{~m}, 1 \mathrm{H})$; $8.93(\mathrm{~m}, 1 \mathrm{H}) .{ }^{13} \mathrm{C}$ NMR (300 MHz, DMSO-d6): $\delta$ (ppm): 124.05; 129.87; 130.29; 138.45; 139.69; $143.46 ; 148.11 ; 155.86 ; 156.51$.

2,3-Diphenyl-5, 6, 7, 8-tetrahydroquinoxaline

(3d, Table 3, Entry 4). M.p.: $153-154^{\circ} \mathrm{C}\left(152-155^{\circ} \mathrm{C}{ }^{37}\right)$; ${ }^{1} \mathrm{H}$ NMR (300 MHz, DMSO-d6): $\delta(\mathrm{ppm}): 1.99-2.03$ $(\mathrm{m}, 4 \mathrm{H}), 3.11(\mathrm{~m}, 4 \mathrm{H}), 7.30-7.33(\mathrm{~m}, 6 \mathrm{H}), 7.44-$ $7.49(\mathrm{~m}, 4 \mathrm{H}) .{ }^{13} \mathrm{C}$ NMR (300 MHz, DMSO-d6): $\delta$ (ppm): 22.9, 32.0, 128.2, 128.4, 129.9, 139.2, $149.8,151.1$.

2,3-Diphenylpyrazine (3e, Table 3, Entry 5). M.p.: $119-120^{\circ} \mathrm{C}\left(121-122^{\circ} \mathrm{C}^{37}\right) ;{ }^{1} \mathrm{H}$ NMR (300 MHz, DMSO-d6): $\delta(\mathrm{ppm}): 7.30-7.37(\mathrm{~m}, 6 \mathrm{H}), 7.43-7.48$ $(\mathrm{m}, 4 \mathrm{H}), 8.62(\mathrm{~s}, 2 \mathrm{H}) .{ }^{13} \mathrm{C}$ NMR $(300 \mathrm{MHz}, \mathrm{DMSO}-$ d6): $\delta(p p m): 128.6,128.9,129.8,139.0,142.4$, 153.1.
2,3-di(furan-2-yI)quinoxaline (3f, Table 3, Entry 6). M.p.: $133-135^{\circ} \mathrm{C}\left(134-136^{\circ} \mathrm{C}{ }^{36-37}\right) ;{ }^{1} \mathrm{H}$ NMR (300 $\mathrm{MHz}, \mathrm{DMSO}-\mathrm{d} 6): \delta(\mathrm{ppm}): 6.59(\mathrm{~m}, 2 \mathrm{H}), 6.68(\mathrm{~m}$, $2 \mathrm{H}), 7.65(\mathrm{~m}, 2 \mathrm{H}), 7.79(\mathrm{~m}, 2 \mathrm{H}), 8.17(\mathrm{~m}, 2 \mathrm{H}) .{ }^{13} \mathrm{C}$ NMR (300 MHz, DMSO-d6): $\delta$ (ppm): 112.00, $112.93,129.06,130.67,140.71,142.85,144.22$.

2,3-di(furan-2-yl)-6-methylquinoxaline (3g, Table 3, Entry 7). M.p.: $124-125^{\circ} \mathrm{C}\left(122-124^{\circ} \mathrm{C}{ }^{36-37}\right) ;{ }^{1} \mathrm{H}$ NMR (300 MHz, DMSO-d6): $\delta(\mathrm{ppm}): 6.71(\mathrm{~m}, 4 \mathrm{H})$, $7.68(\mathrm{~m}, 3 \mathrm{H}), 7.99(\mathrm{~s}, 1 \mathrm{H}), 7.99(\mathrm{~m}, 1 \mathrm{H}) .{ }^{13} \mathrm{C} N M R$ (300 MHz, DMSO-d6): $\delta$ (ppm): 21.46, 111.42, $111.97,112.40,127.30,127.88,132.21,138.53$, $139.98,140.65,141.12$, 141.92, 143.35, 143.52, 150.40 .

2,3-di(furan-2-yl)-6-nitroquinoxaline (3h, Table 3, Entry 8). M.p.: $154-156^{\circ} \mathrm{C}\left(152-154^{\circ} \mathrm{C}{ }^{36-37}\right) ;{ }^{1} \mathrm{H}$ NMR (300 MHz, DMSO-d6): $\delta$ (ppm): 6.62-6.65 (m, $2 \mathrm{H}), 6.97(\mathrm{~m}, 2 \mathrm{H}), 7.68(\mathrm{~m}, 2 \mathrm{H}), 8.32(\mathrm{~m}, 1 \mathrm{H})$, $8.59(\mathrm{~m}, 1 \mathrm{H}), 9.04(\mathrm{~m}, 1 \mathrm{H}) .{ }^{13} \mathrm{C} \mathrm{NMR}(300 \mathrm{MHz}$, DMSO-d6): $\delta$ (ppm): 111.38, 111.52, 113.55, $114.38,122.49,123.98,129.47,137.98,141.88$, $142.98,143.45,143.95,144.41,146.64,148.89$, 148.98.

2,3-Di(2-furyl)-5,6,7,8-tetrahydroquinoxaline (3i, Table 3, Entry 9). M.p.: $150^{\circ} \mathrm{C}\left(150-151^{\circ} \mathrm{C}{ }^{37}\right) ;{ }^{1} \mathrm{H}$ NMR (300 MHz, DMSO-d6): $\delta$ (ppm): 1.91-1.97 (m, $4 \mathrm{H}), 2.99-3.04(\mathrm{~m}, 4 \mathrm{H}), 6.45-6.51(\mathrm{~m}, 4 \mathrm{H}), 7.50$ $7.51(\mathrm{~m}, 2 \mathrm{H}) .{ }^{13} \mathrm{C}$ NMR (300 MHz, DMSO-d6): $\delta$ (ppm): 22.65, 31.87, 111.34, 111.63, 139.22, $143.35,150.77,150.81$.

2,3-Di(2-furyl)pyrazine (3j, Table 3, Entry 10). M.p.: $77-78^{\circ} \mathrm{C}\left(78-80^{\circ} \mathrm{C}{ }^{37}\right) ;{ }^{1} \mathrm{H}$ NMR $(300 \mathrm{MHz}$, DMSO-d6): $\delta$ (ppm): 6.53-6.72 (m, 4H), 7.56-7.57 $(\mathrm{m}, 2 \mathrm{H}), 8.53(\mathrm{~m}, 2 \mathrm{H}) .{ }^{13} \mathrm{C}$ NMR $(300 \mathrm{MHz}$, DMSOd6): $\delta(\mathrm{ppm}): 111.82,112.15,112.33,141.76$, $143.84,150.40$. 


\section{${ }^{1} \mathrm{H}$ and ${ }^{13} \mathrm{C}$ NMR spectra of Quinoxalines:}
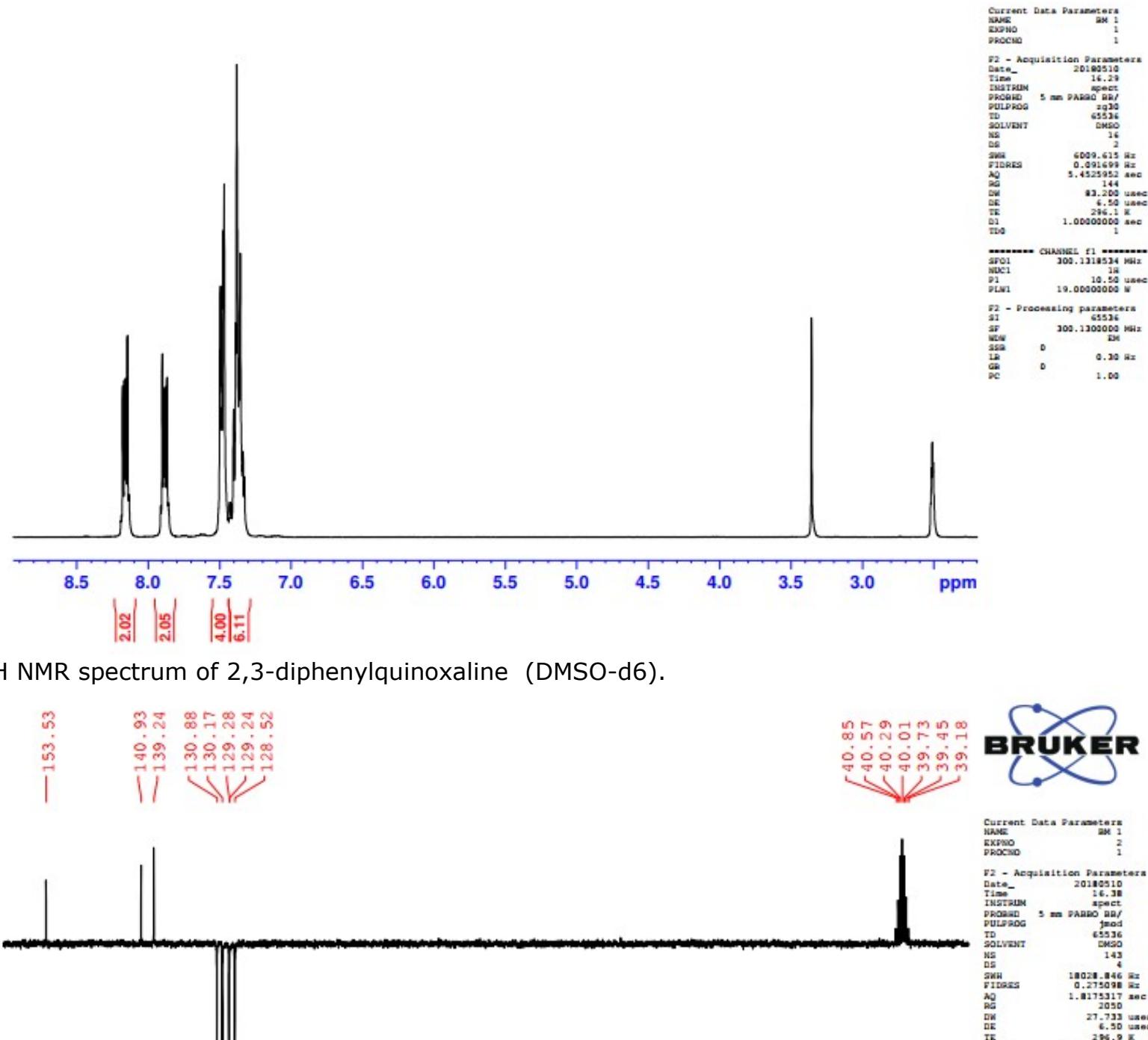

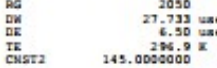

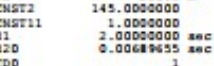

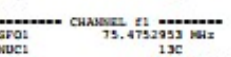

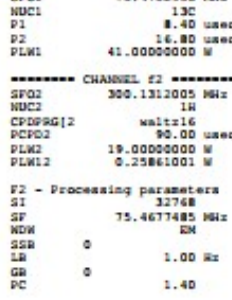

$\begin{array}{lllllllllllll}150 & 140 & 130 & 120 & 110 & 100 & 90 & 80 & 70 & 60 & 50 & 40 & \mathrm{ppm}\end{array}$

${ }^{13} \mathrm{C}$ NMR spectrum of 2,3-diphenylquinoxaline (DMSO-d6). 


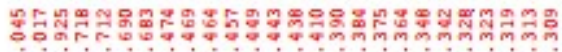 $\underbrace{20}$}

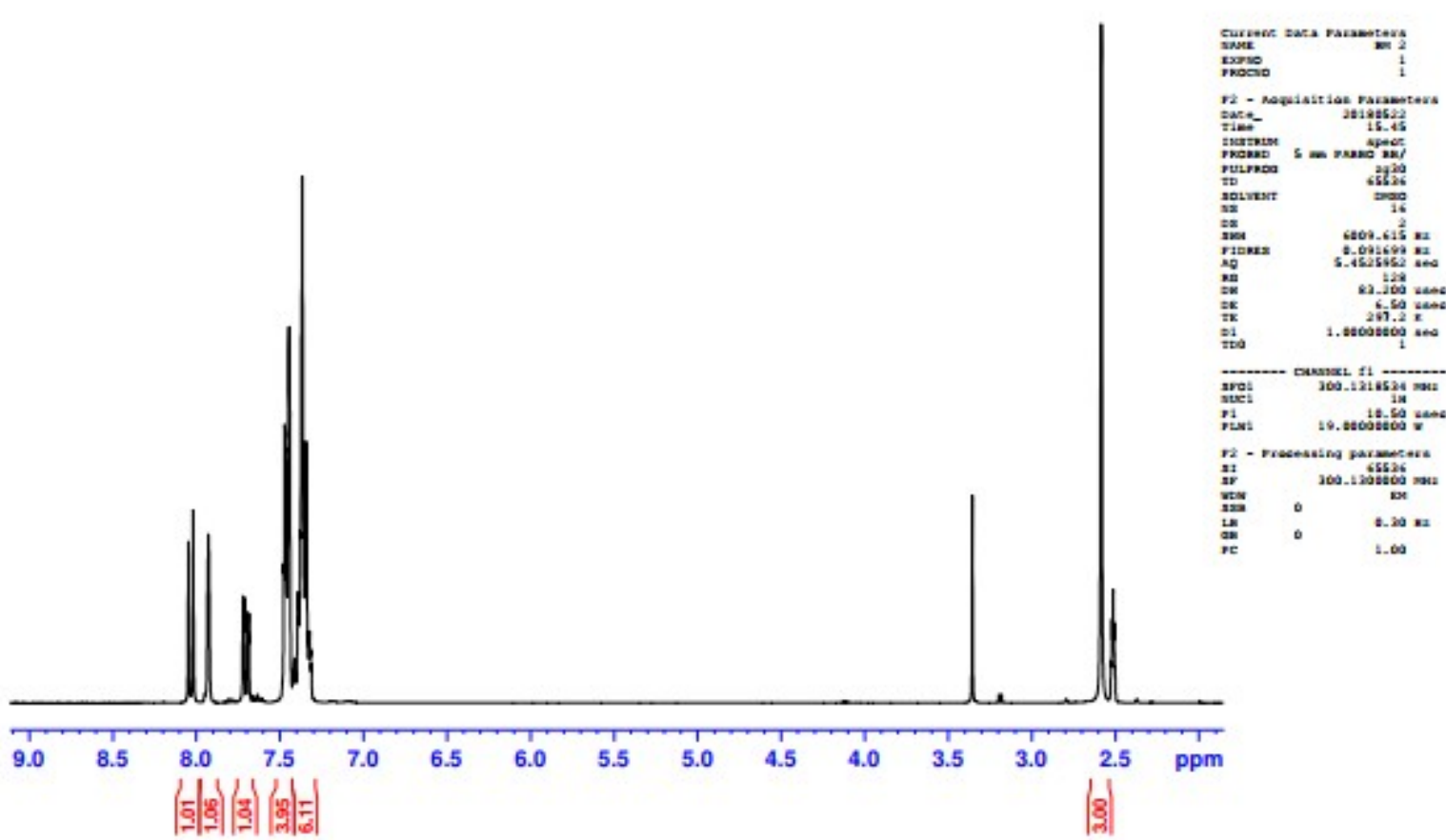

${ }^{1} \mathrm{H}$ NMR spectrum of 6-methyl-2,3-diphenylquinoxaline (DMSO-d6).
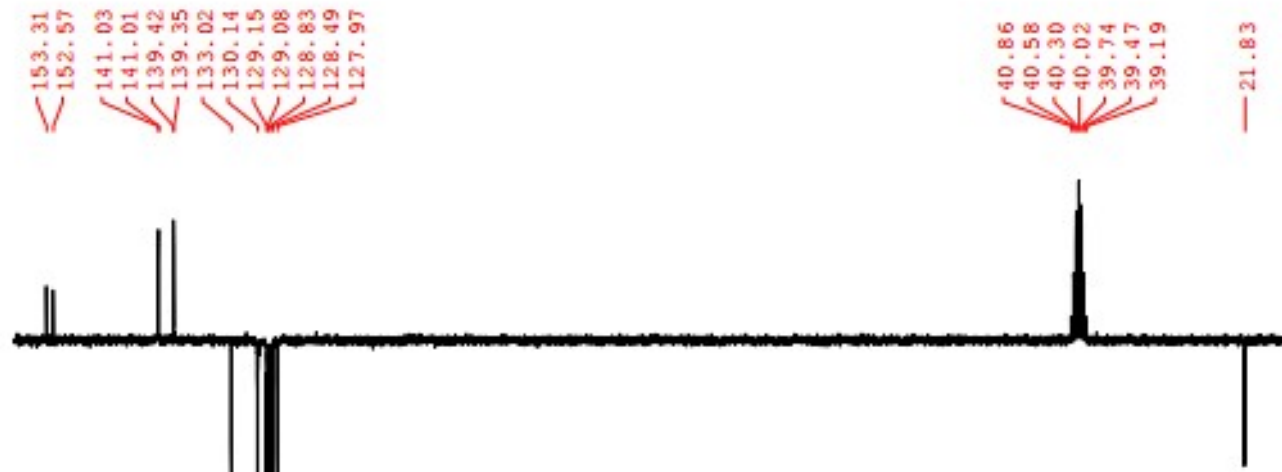

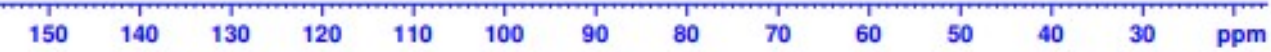

${ }^{13} \mathrm{C}$ NMR spectrum of 6-methyl-2,3-diphenylquinoxaline (DMSO-d6).

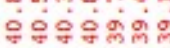
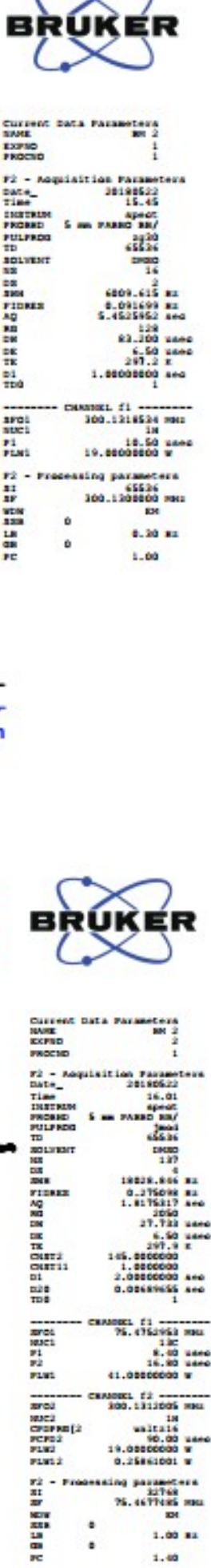

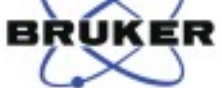

ㅊ.

BRUKER

1. 

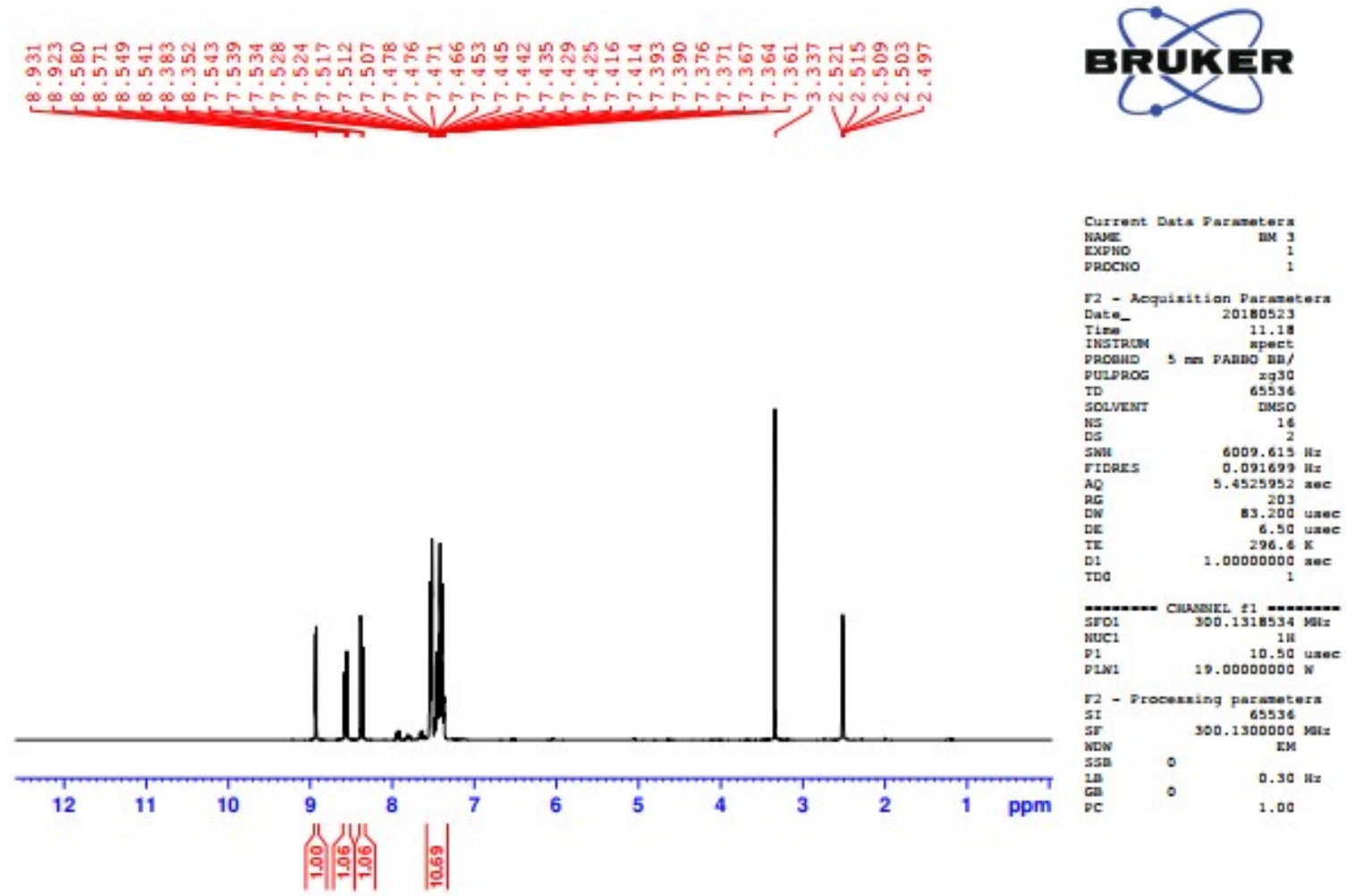

${ }^{1} \mathrm{H}$ NMR spectrum of 6-nitro-2,3-diphenylquinoxaline (DMSO-d6).
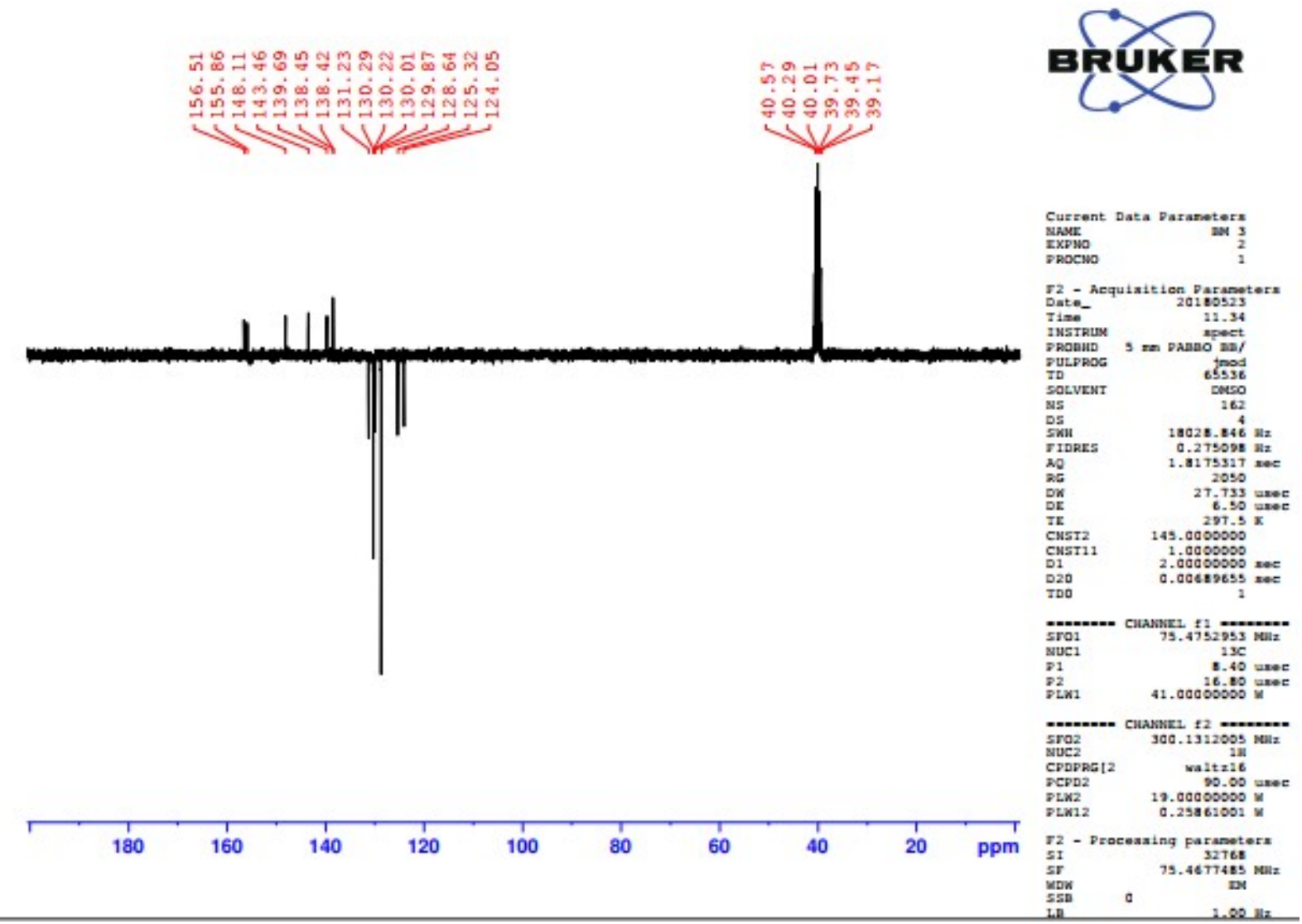

${ }^{13} \mathrm{C}$ NMR spectrum of 6-nitro-2,3-diphenylquinoxaline (DMSO-d6). 


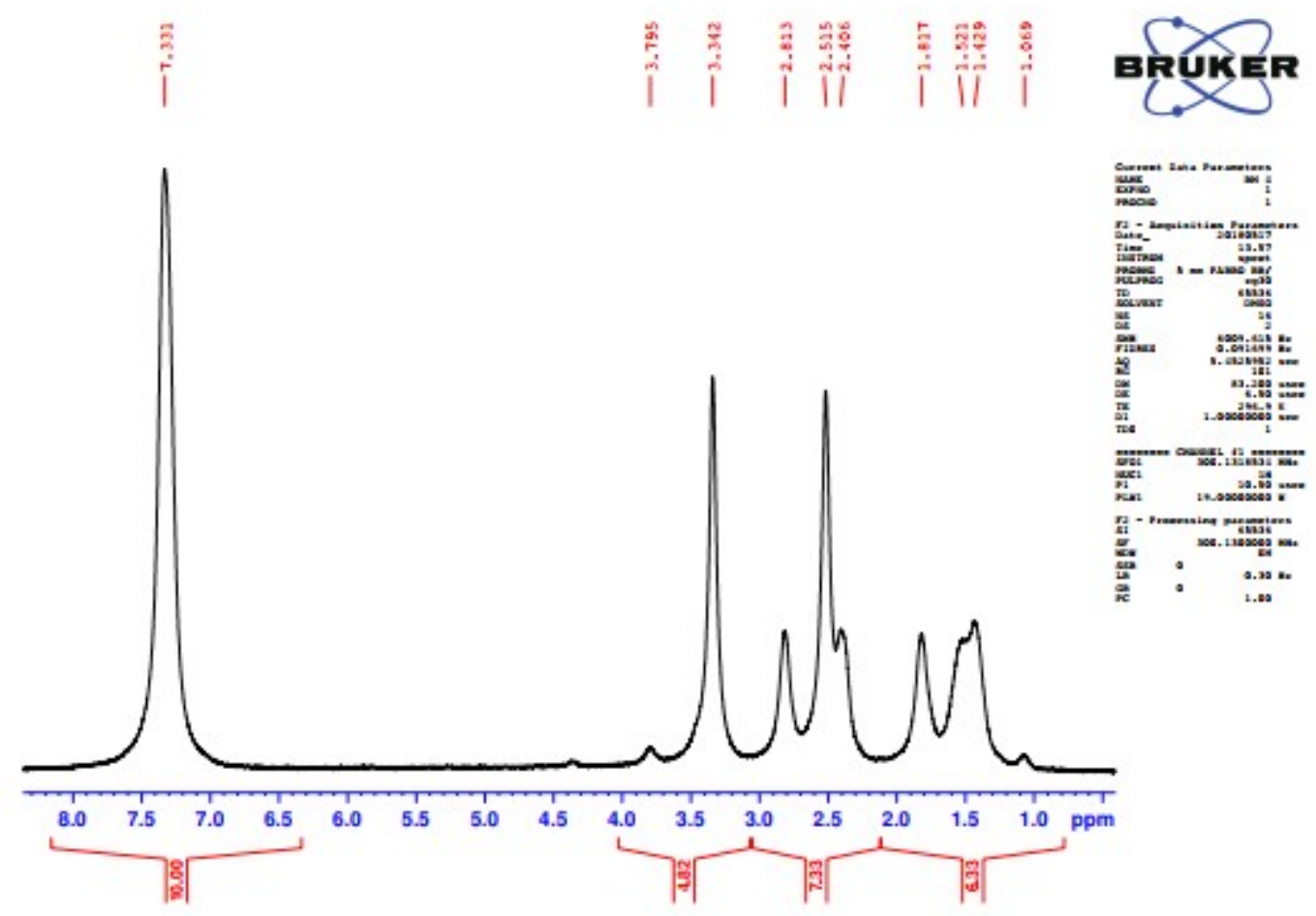

${ }^{1} \mathrm{H}$ NMR spectrum of 2,3-Diphenyl-5,6,7,8-tetrahydroquinoxaline (DMSO-d6).
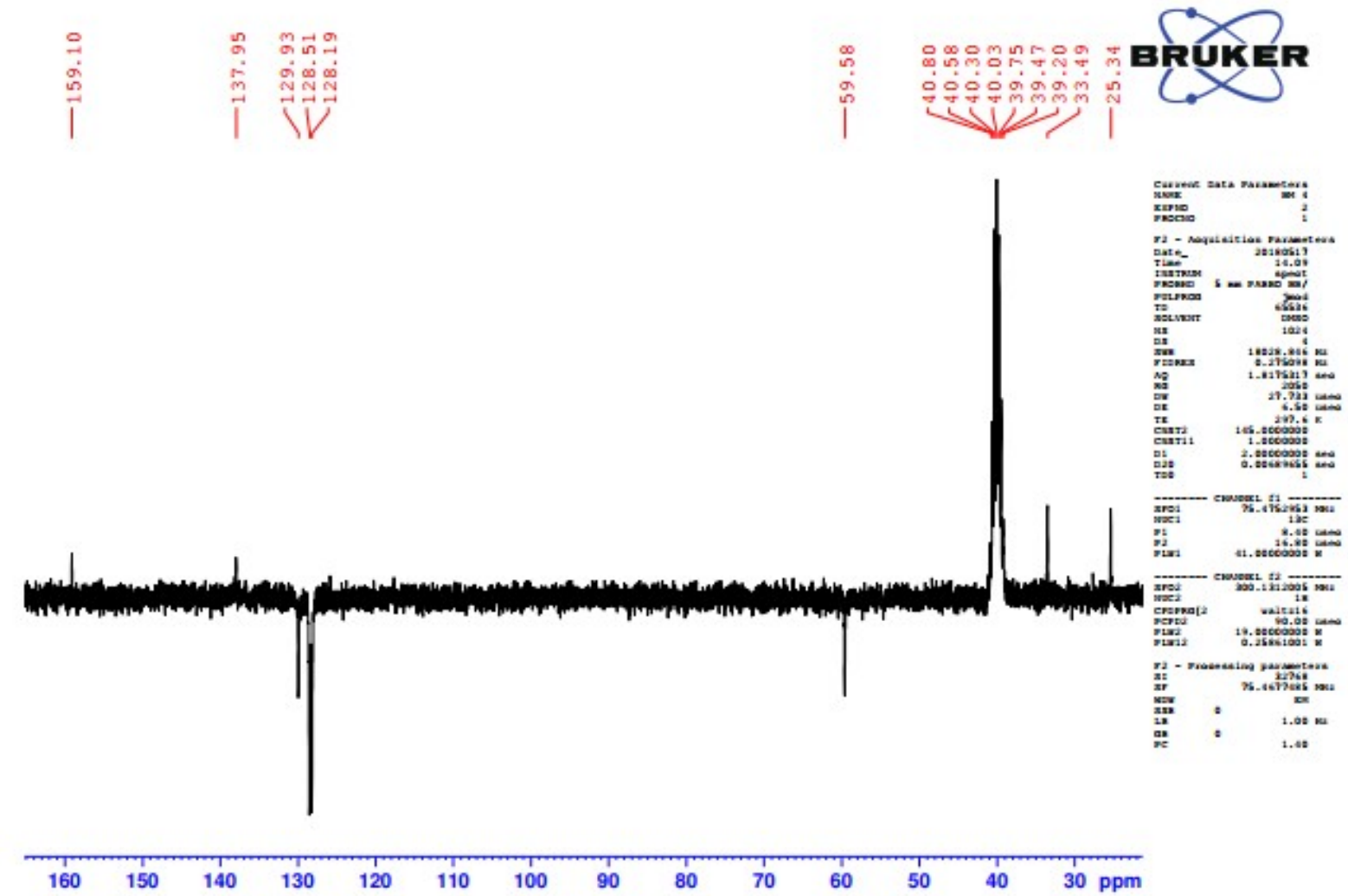

${ }^{13} \mathrm{C}$ NMR spectrum of 2,3-Diphenyl-5,6,7,8-tetrahydroquinoxaline (DMSO-d6). 


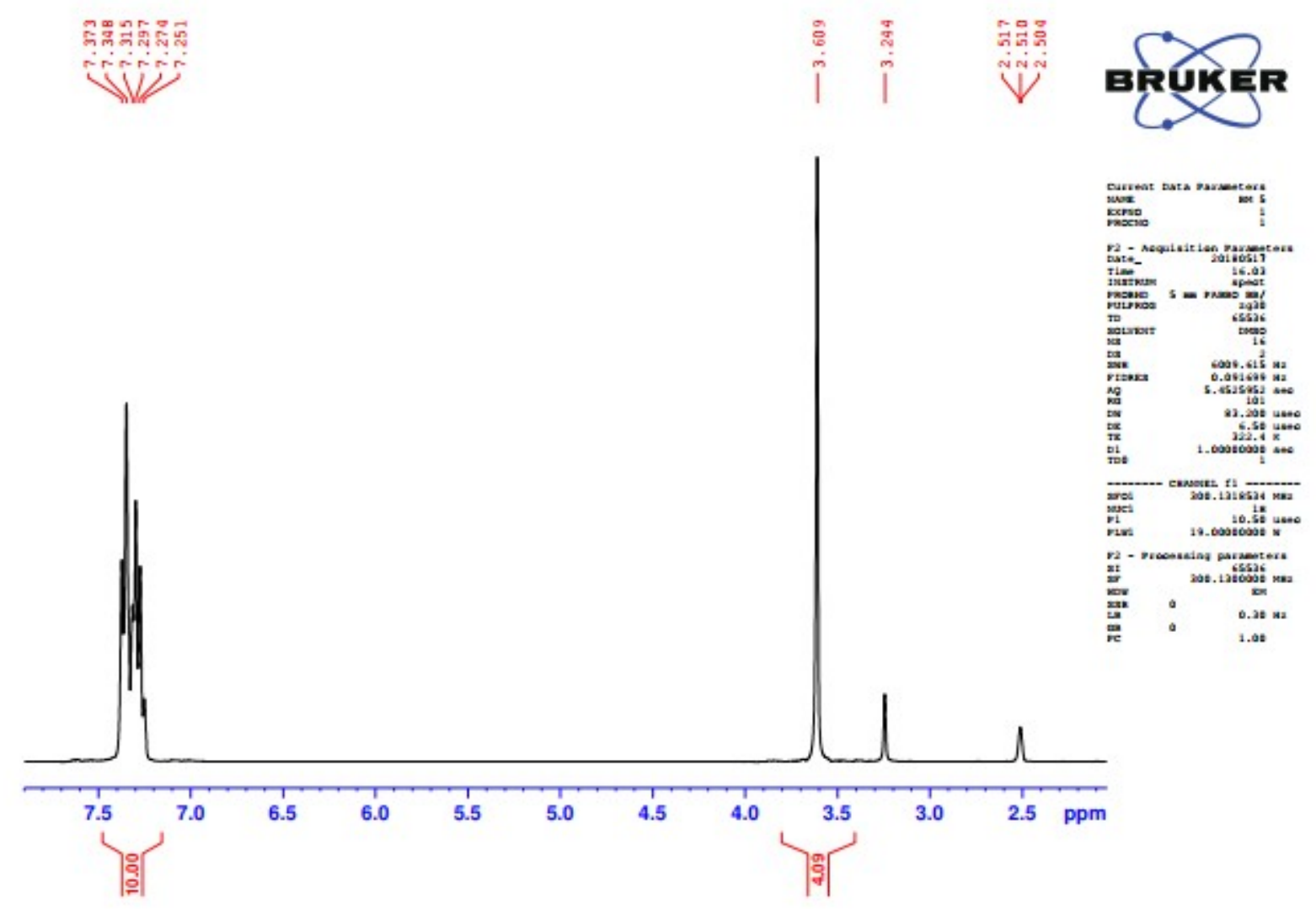

${ }^{1} \mathrm{H}$ NMR spectrum of 2,3-Diphenylpyrazine (DMSO-d6).

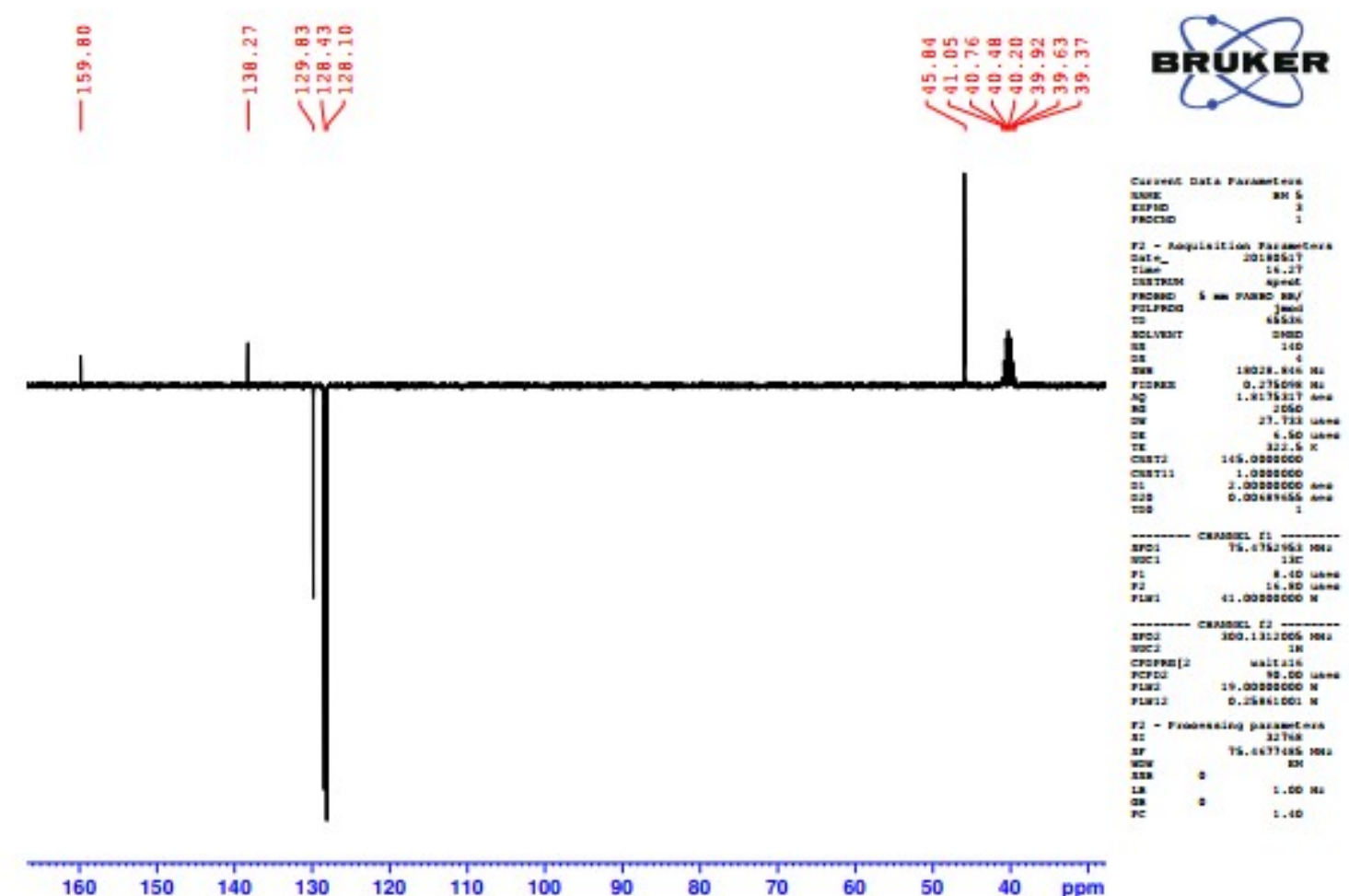

${ }^{13} \mathrm{C}$ NMR spectrum of 2,3-Diphenylpyrazine (DMSO-d6). 